\title{
Effect of Zn Doping in CdS Thin Films on Structural, Morphological and Optical Characterization
}

\author{
B. S. Munde ${ }^{1}, *$ L. S. Ravangave ${ }^{2}$ \\ ${ }^{I}$ K. K. M. College Manwat Dist. Parbhani (MS) India \\ ${ }^{2}$ Shri Sant Gadge Maharaj Mahavidyalaya, Loha, Dist. Nanded (MS) India
}

\begin{abstract}
In this particular experiment we employ Chemical Bath deposition Technique. Initially the bath parameters such as temperature, $\mathrm{pH}$ of the precursors, molarity of the solutions, deposition time were optimized for synthesis of $C d S$ thin films. Using above optimized parameters, we prepare $C d_{1-x} Z n_{x} S$ thin films for the study of effect of Zn concentration on various properties of the films. The structural, Morphological and optical characterization were investigated. The XRD spectra of the $C d_{1-x} Z n_{x} S$ films exhibit the hexagonal crystal structure with preferential orientations at (100), (002), (101), (203), (102), (110), (200) and (004) planes. The planes (101), (002), (100) exhibited the wurtzite (hexagonal type) structure. XRD pattern shows increase in half width at full maximum with Zn content. SEM micrograph shows the porous fibrous network consisting of regularly arranged matrix over which regular shaped fine particles systematically distributed. The effect of Zn concentration in $\mathrm{Cd}_{1-x} \mathrm{Zn} \mathrm{n}_{x} \mathrm{~S}$ thin films clearly understood from the improvement in the microstructure of the surface morphology. The optical spectra show that absorption was found decreased with $\mathrm{Zn}$ content of the $\mathrm{Cd}$. ${ }_{x} Z n_{x}$ S.The absorption spectra shows the significant blue shifting of absorption edge (approximately from 450 $325 \mathrm{~nm}$ ). The optical transmittance was found maximum in the visible region $(450-800 \mathrm{~nm})$ and increased on increasing the $\mathrm{Zn}$ concentration. The $x=0.2$ composition having maximum transmittance $78 \%$ show the maximum $3.9 \mathrm{eV}$ optical band gap which may be high enough for solar cell applications.
\end{abstract}

Keywords: CdZnS Thin films, Optical Properties, Chemical Bath Deposition Method.

\section{Introduction}

The solar energy has greatest potential of all the sources of renewable energy. Various types of thin film solar cells exists today; the major contributors being crystalline silicon, amorphous crystalline galliumarsenide, poly-crystalline copper-indium gallium di-sellenide (CuIGS) and polycrystalline cadmium telluride ( CdTe) [1]. In the past few years, II-IV semiconductors thin films have attracted considerable attention. In the architecture of photo voltaic devices, the cadmium Sulphide (CdS) was mostly used as a window layer[2,3]. Addition of $\mathrm{Zn}$ to the most widely used CdS buffer layer material enhances the electronic, electrical, optical properties of devices. It has been widely used as a wide band gap window material in hetro-junction solar cells and photoconductive devices[4,5]. In present work contributed to synthesis, of $\mathrm{Cd}_{1-\mathrm{x}} \mathrm{Zn}_{\mathrm{x}} \mathrm{S}$ thin films and study the structural, Morphological and optical properties. Various techniques are available for preparation of $\mathrm{Cd}_{1-}$. ${ }_{x} \mathrm{Zn}_{\mathrm{x}} \mathrm{S}$ thin films. We employed Chemical bath deposition technique which is very economic, simple, invasive less time consume ales chemical wastage and required less instrumentation.

\section{Material and methods:}

In order to prepare $\mathrm{Cd}_{1-\mathrm{x}} \mathrm{Zn}_{\mathrm{x}} \mathrm{S}$ thin films, the chemicals cadmium chloride $\left(\mathrm{CdCl}_{2}\right)$, zinc chloride $\left(\mathrm{ZnCl}_{2}\right)$ and thiourea $\left(\mathrm{NH}_{2} \mathrm{CSNH}_{2}\right)$ were used as $\mathrm{Cd}^{+2}, \mathrm{Zn}^{+2}$ and $\mathrm{S}^{-2}$ ions respectively. The stock solutions of $\mathrm{CdCl}_{2}$ $(0.25 \mathrm{M}), \mathrm{ZnCl}_{2}(0.25 \mathrm{M})$ and $\mathrm{NH}_{2}-\mathrm{CS}-\mathrm{NH}_{2}(0.3 \mathrm{M})$ were prepared as previously optimized. The experimental solutions were taken in reaction beaker for deposition of $\mathrm{Cd}_{1-\mathrm{x}} \mathrm{Zn}_{\mathrm{x}} \mathrm{S}(\mathrm{x}=0.0,0.2,0.4,0.6,0.8,1.0)$ and thiourea 10 $\mathrm{ml}$. The $\mathrm{pH}$ of the solution was adjusted to 11 by adding the aqueous $\mathrm{NH}_{3}$. The reaction beaker was kept in temperature bath, maintained at constant $80^{\circ} \mathrm{C}$. Glass substrates were cleaned by $24 \mathrm{hr}$ immersion in chromic acid, rinsed with acetone and distilled water. The cleaned glass substrates were kept vertical in reaction beaker with constant stirring for 35 minutes. The deposited substrates were removed after 35 minutes and dried in air, and annealed for an hour at $100{ }^{\circ} \mathrm{C}$. The annealed films are then subjected to different characterizations.

\section{Results And Discussion}

The film thickness variation with concentration was given in table 1 and was fond increased with zn content.

\section{a. Xrd study:}

The XRD pattern is presented in figure 1. The XRD pattern of $\mathrm{Cd}_{1-\mathrm{x}} \mathrm{Zn}_{\mathrm{x}} \mathrm{S}$ thin films exhibit the wurtzite (hexagonal type) structure with preferential orientations at (100), (002), (101), (203), (102), (110), (200) and 
(004) planes, at $2 \theta=25.31,26.756,29.59,31.20,37.9,52.10$ and 55.60. The observed diffraction patterns are in good agreement with the standard JCPDS card data: 49-1302. It is observed that with increase in $\mathrm{Zn}$ content in the composition only (002) peak is significant and intensity of other peaks decreased. The average particle size estimated by using Scherrer's relation (1) and presented in table 1.

$$
\mathrm{D}=0.9 \lambda / \beta \cos \Theta \quad--\quad(1)
$$

where, $\mathrm{D}$ is crystallite size, $\lambda$ is wavelength of $\mathrm{X}$-ray used, $\beta$ is full width at half maxima of the peak (FWHM) in radians, $\Theta$ is Bragg's angle. The grain size indicates that the deposited $C_{1-x} Z_{x} S$ thin films exhibit the nanostructure. The variation of grain size is in between 24 to $45 \mathrm{~nm}$.

\section{b. Scanning Electron Microscopic Study for Surface Morphology of $\operatorname{Cd}_{1-x} \mathbf{Z n}_{\mathrm{x}} S$}

In order to investigate the effect of $\mathrm{Zn}$ content on the surface morphology of the prepared $\mathrm{Cd}_{1-\mathrm{x}} \mathrm{Zn}_{\mathrm{x}} \mathrm{S}$ thin films were scanned by using Scanning electron microscopy (SEM Model: Quanta 200 ESEM). The SEM micrographs of six different $\mathrm{Cd}_{1-\mathrm{x}} \mathrm{Zn}_{\mathrm{x}} \mathrm{S}$ thin films were presented in figures 2. (1through 6).

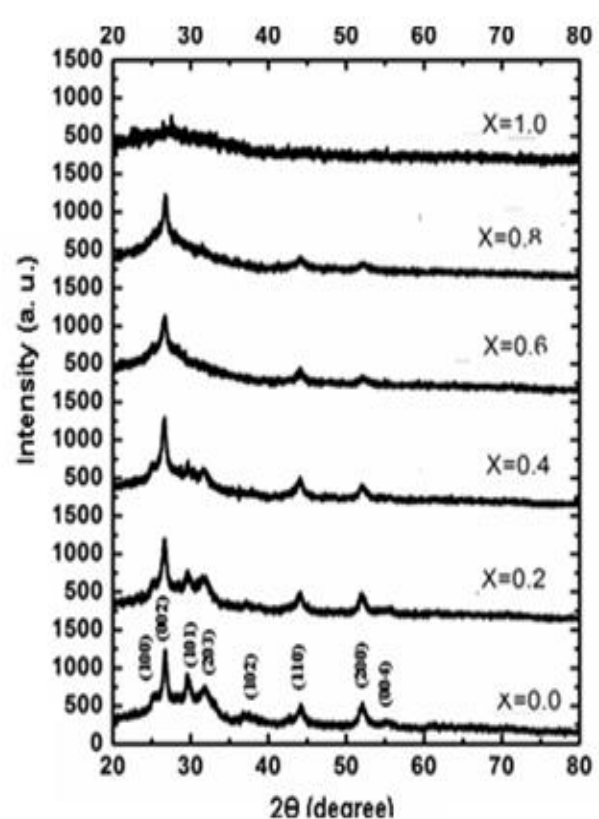

Fig 1. XRD Pattern of $\mathrm{Cd}_{1 \cdot x} \mathrm{Zn}_{\mathrm{x}} \mathrm{S}$ thin films

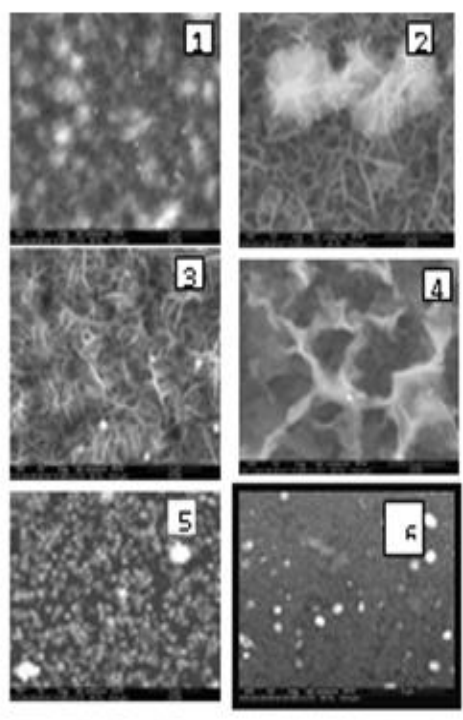

Figure 2. The SEM migograple of $\mathrm{Cd}, \mathrm{Zn}_{1}, \mathrm{~S}$ thin film [1) for $x=0.0,2)$ for $x=0.2,3$ ) for $x=0.4,4$ ) for $x=0.6$ and 5$)$ for $x=08$ and 6$) x=1.0$ ]

All the films were scanned at $15 \mathrm{KX}$ magnifications. The micrograph shows that the films deposited cover the whole substrate with uniform surface morphology. The thin films exhibit $\mathrm{Cd}_{1-\mathrm{x}} \mathrm{Zn}_{\mathrm{x}} \mathrm{S}$ nano wires increased dimension up to few $\mu \mathrm{m}$ size due to agglomeration. The improvement in the microstructure was observed up to $\mathrm{x}=0.8$ composition. The uniform surface morphology changes into granular type morphology.

\section{Optical Study:}

Absorbance data of $\mathrm{Cd}_{1-\mathrm{x}} \mathrm{Zn}_{\mathrm{x}} \mathrm{S}$ thin films was recorded by using UV-Visible spectrophotometer (Systronics Double Beam 2201). The variation of absorption with wavelength was presented in figure 3 . The percentage (\%) absorption was found decreased with $\mathrm{Zn}$ concentration. The absorption spectra shows the blue shifting of absorption edge (approximately from $450-325 \mathrm{~nm}$ ). The blue shifting was significant for the composition $\mathrm{x}=0.4,0.6,0.8,1.0$. Ravangve L. S. et al.(2013) were reported blue shifting of absorption edge indicates that, the prepared films exhibit low absorption in the blue region. The blue shifting of absorption edge indicate the decrease in optical absorption in the blue portion of the solar spectrum[6]. All the $\mathrm{Cd}_{1-\mathrm{x}} \mathrm{Zn}_{\mathrm{x}} \mathrm{S}$ films shows high absorption coefficient $\left(\alpha=10^{7} \mathrm{~cm}^{-1}\right)$. The values of the direct band gap (Eg) were determined by plotting $(\alpha \mathrm{h} v)^{2}$ versus photon energy (eV) as shown in Fig. 4. and using equation (2).

$$
\alpha=(\mathrm{A} / \mathrm{h} v)(\mathrm{h} v-\mathrm{Eg})^{\mathrm{n}} \quad---(2)
$$




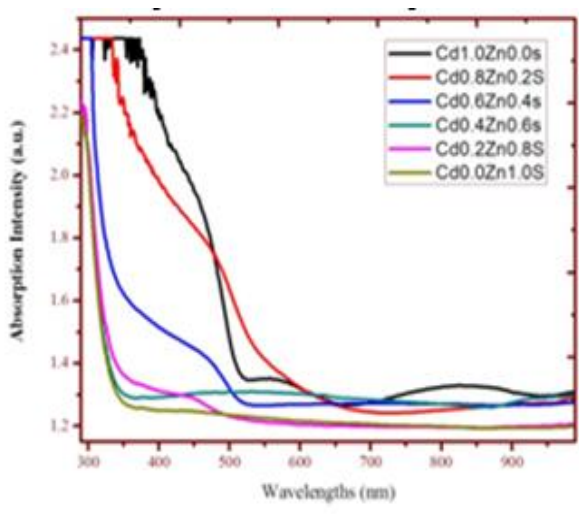

Fig 3. Absorption Spectra of $\mathrm{Cd}_{x} \mathrm{Zn}_{1 \cdot x} S$ thin films

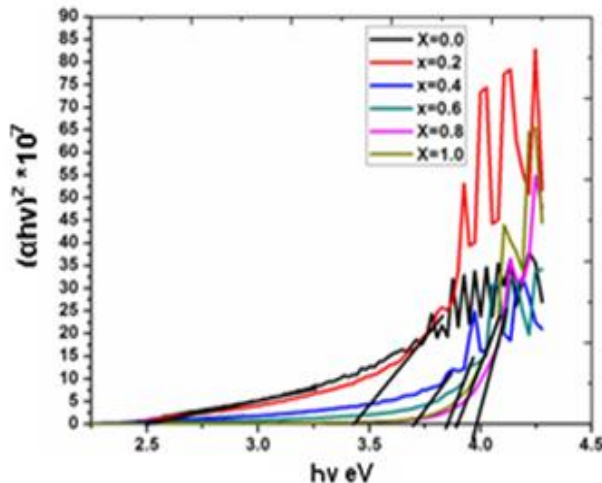

Fig 4. Plot of $(a h v)^{2}$ vs photon energy hv

where $\mathrm{A}$ is a constant depending upon the transition probability for direct transition, $\mathrm{n}=1 / 2$ or $3 / 2$ depending on whether the transition is allowed or forbidden in the quantum mechanical sense. Eg is the optical gap in $(\mathrm{eV})$. The band gap was increased with $\mathrm{Zn}$ content from 2.45 to $3.91 \mathrm{eV}$. In the composition $\mathrm{x}=0.8$, the band gap was found to be $3.91 \mathrm{eV}$. The variation of band gap with concentration of $\mathrm{Zn}$ was displayed in figure 5.The results and discussion of the study concluded that $\mathrm{Cd}_{\mathrm{x}} \mathrm{Zn}_{1-\mathrm{x}} \mathrm{S}(\mathrm{x}=0.8)$ thin film may be used as an ideal alternative window material to $\mathrm{CdS}$ and $\mathrm{ZnS}$ for solar cell devices. The variation of band gap versus composition (x) was presented in figure 5. The maximum band gap $3.91 \mathrm{eV}$ was observed for $\mathrm{Cd}_{1-\mathrm{x}} \mathrm{Zn}_{\mathrm{x}} \mathrm{S}$ thin films for the composition $x=0.8$. The optical transmittance versus wavelength was presented in Fig. $6 . \quad$ The optical transmittance is higher in the visible region $(350-8500 \mathrm{~nm})$ and found increased from 5 to $70 \%$ with $\mathrm{Zn}$ content. In the composition $\mathrm{x}=0.8$, the observed transmittance was $78 \%$. Nathera A. (2012) were reported maximum 58\% transmittance for $\mathrm{CdZnS}$ thin films which is high enough for solar cell application [7].

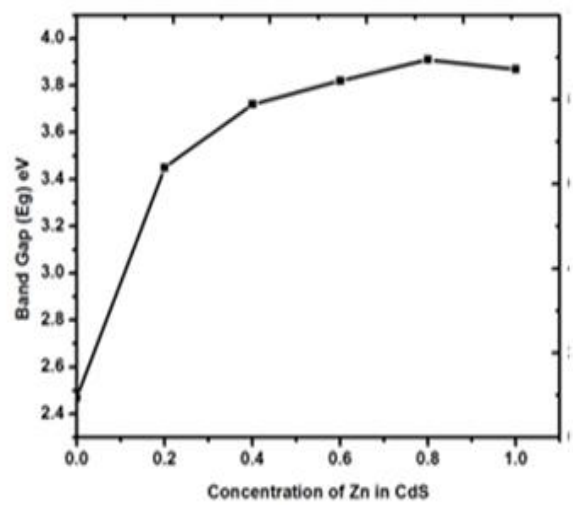

Fig 5 Variation of Band gap Eg (eV) Vs Coposition

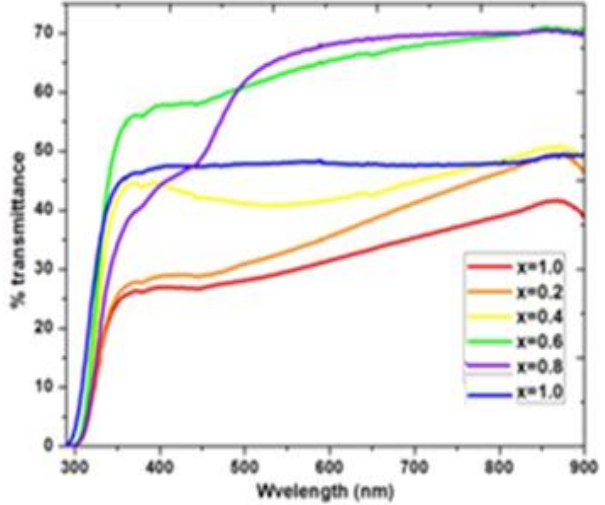

Fig 6. Persentage transmittance Vs Wavelength (nm)

\begin{tabular}{|c|c|c|c|c|}
\hline Sr. No. & $\begin{array}{l}\text { Concentration of } \\
\operatorname{Zn}(\mathbf{X})\end{array}$ & Film thickness $(\mu \mathrm{m})$ & $\begin{array}{ll}\begin{array}{l}\text { Grain } \\
(\mathbf{n m})\end{array} & \text { Size } \\
\end{array}$ & $\begin{array}{l}\text { Band Gap } \\
(\mathrm{eV})\end{array}$ \\
\hline & 00 & 1.33 & 24 & 2.47 \\
\hline & 0.2 & 1.67 & 24.82 & 3.46 \\
\hline & 0.4 & 2.13 & 29 & 3.72 \\
\hline & 0.6 & 2.23 & 35 & 3.82 \\
\hline & 0.8 & 2.43 & 36 & 3.91 \\
\hline & 1.0 & 2.63 & 45 & 3.87 \\
\hline
\end{tabular}

\section{Conclusion}

CBD technique is convenient tool for deposition $\mathrm{Cd}_{1-\mathrm{x}} \mathrm{Zn}_{\mathrm{x}} \mathrm{S}$ thin films. The structural, Morphological and optical study concluded that the composition $\mathrm{Cd}_{0.2} \mathrm{Zn}_{0.8} \mathrm{~S}$ exhibit band gap $3.91 \mathrm{eV}$ and $72 \%$ transmittance is very useful combination for solar cell window layer material. 


\section{Acknowledgements}

Author B.S.Munde is thankful to UGC(WRO)Pune for financial assistance under the Minor Research Project[F.No.:47-715/13(WRO)] and Physics Research Centre, S.S.G.M. College, Loha Dist. Nanded for Characterization Techniques.

\section{Referecnes}

[1]. A.R. West, 'Solid State Chemistry' John willey and Sons, Singapore, (2003)

[2]. K. L. Chopra, 'Thin Film Phenomena', McGraw Hill, New York (1969)

[3]. Y. Gao, H. Niu, C. Q. Chen, Chem. Phys. Lett. 367 (1-2) (2003) 141

[4]. Zeng Acosta, R.E., Romankiw, L.T., Von Gutfeld, R. J. Thin Sol. Films 95 (1982) 13

[5]. Becker, J. S. Atomic Layer Deposition of Metal Oxide and Nitride Thin Films, Ph. D. Thesis, Harvard University Cambridge, Massachusetts (2002).

[6]. L. S. Ravangave, S. D. Misal \& U. V. Biradar, 'Optics and Photonics Letters' World Scientific Publishing Company,Vol.6 (1), 1350006 (2013).

[7]. A. Nathera et al Material Physics and Chemistry 2 (2012) 69-67.

IOSR Journal of Applied Physics (IOSR-JAP) is UGC approved Journal with Sl. No. 5010, Journal no. 49054

B. S. Munde. "Effect of Zn Doping In CDS Thin Films on Structural, Morphological and Optical Characterization ." IOSR Journal of Applied Physics (IOSR-JAP) 9.4 (2017): 50-53. 